
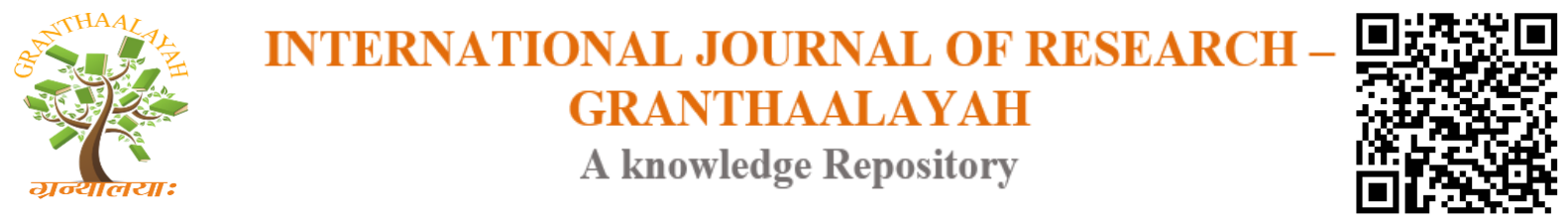

Management

\title{
E-GOVERNMENT SUCCESS FACTORS FROM A BUSINESSES PERSPECTIVE IN DEVELOPING COUNTRIES: A CASE OF JORDAN
}

\author{
Anas Ghassan Kanaan ${ }^{1}$, Shahizan Bin Hassan ${ }^{2}$ \\ ${ }^{1,2}$ Universiti Utara Malaysia, School of Technology Management \& Logistics, Othman Yeop \\ Abdullah (OYA) Graduate School of Business, Box-06010, Kedah, MALAYSIA
}

DOI: https://doi.org/10.29121/granthaalayah.v4.i11.2016.2415

\section{ABSTRACT}

This paper presents a study which examines several e-government success factors in Jordan. Due to the pace of globalization and rapid global growth of technology and the Internet information, many governments around the world have turned their services from traditional services into e-government services. Were the citizens, business organizations and other stakeholders are served via the internet. Jordan is one of the rare countries in the Middle East with a history of commitment to good governance and ICT-related initiatives. In recent years, Jordan's efforts to provide e-government services to the public have been recognized. But still Jordan faces the problem of low usage levels of these electronic services, plus several scholars addressed that several studies were conducted from citizen perspective but few for businesses perspective. For a better understanding of e-government and its influence on the society as all and on the business society in particular the researchers carried out this study to identify the success factors which affect e-government adoption in Jordan, also to investigate the factors that determine business organization satisfaction towards e-government in Jordan. In this paper the researcher will discuss four factors that affect the success of e-government services from businesses perspective in Jordan as followed: e-service quality, perceived usefulness, trust, personalization.

Keywords:

E-government success, e-service quality, perceived usefulness, trust, personalization, Jordan Egovernment.

Cite This Article: Anas Ghassan Kanaan, and Shahizan Bin Hassan, "E-GOVERNMENT SUCCESS FACTORS FROM A BUSINESSES PERSPECTIVE IN DEVELOPING COUNTRIES: A CASE OF JORDAN" International Journal of Research - Granthaalayah, Vol. 4, No. 11 (2016): 1-12.

\section{INTRODUCTION}

E-government is the way for governments to use the most innovative ICT services, in some specific web-based Internet applications (Ancarani, 2005). Information and communication 
technologies (ICT) have revolutionized the processes, operations and structures of public sectors in both developed and developing countries (Rana et al. 2015). Jordan is "one of the rare countries in the Middle East with a history of commitment to good governance and ICT-related initiatives", (Ciborra \& Navarra, 2005: p.142).

In recent years, Jordanian government are giving efforts to provide e-government services to public (Alomari, Sandhu, \& Woods, 2010). Although e-government program in Jordan is still at the initial stages, Jordan has developed relatively advanced e-government service delivery capabilities in two-way interaction and e-democracy (Chatfield \& Alhujran, 2009). In addition, the United Nations' e-government readiness reports ranked Jordan as one of the top 5 among the Arab countries (UN, 2005). Nonetheless, e-government in Jordan faces the problem of low usage levels of these electronic services (Al-Hujran et al., 2013; Al-Jaghoub, Al-Yaseen, \& AlHourani, 2010; Mofleh, Wanous, \& Strachan, 2008; Rana \& Dwivedi, 2015). As of 2010, More than $85 \%$ of Jordanians never used e-government websites and electronic services (Al-Jaghoub et al., 2010).

This paper thus intends to investigate several success factors of e-government application usage for business organizations in Jordan. Several scholars addressed that few studies were carried out from businesses perspective. For a better understanding of e-government and its influence on the society as all and on the business society in particular the researchers carried out this study to identify the success factors which affect e-government in Jordan, also to investigate the factors that determine business organization satisfaction towards e-government in Jordan. In this paper the researchers will discuss four factors that affect the success of e-government services from businesses perspective in Jordan as followed: e-service quality, perceived usefulness, personalization and trust.

\section{PROBLEM STATEMENT}

Several issues faces the e-government in developing countries but in particular for this study, Jordan faces the problem of low usage levels of these electronic services (Al-Hujran et al., 2013; Al-Jaghoub, Al-Yaseen, \& Al-Hourani, 2010; Mofleh, Wanous, \& Strachan, 2008; Rana \& Dwivedi, 2015). There are several studies conducted in citizen perspective in Jordan but very few in businesses perspective (Abdalla, 2012; Alomari, Sandhu \& Woods, 2009; Alawneh et al. 2013; Alomari, 2014). Alomari et al. (2014) mentioned that participants from their previous study declared that the "lack of IT infrastructure" could lead the Jordanian citizens to face lack of trust to the existing security systems that are used by their government therefore doubting their abilities to secure their personal information". These findings are similar and in line with previous studies that show that trust in the internet in terms of security and privacy is a significant predictor of e-government usage in developed and developing countries (Carter \& Be'langer, 2005; Chang et al. 2005; Gilbert, Balestrini \& Littleboy, 2004; Phang et al. 2005).

\section{SUCCESS FACTORS OF E-GOVERNMENT}

\section{TRUST AS A SUCCESS MEASURE}

Another area of research that has received a lot of attention is business' use of e-government and trust and confidence in government (Morgeson, VanAmburg, \& Mithas, 2010). Trust in 
government has long been studied in the political science literature. Trust essentially means that citizens have confidence that their government will make the right decisions. The role of government is normally and traditionally that of protector and provider of services to its citizens. Citizen satisfaction is developed in terms of the quality of this protection by the government, and this also applies in the context of e-government systems. On the government side, its ability to perform its service as a protector, depends on their ability to gather intelligence or information on the needs of citizens, and based on such information; provide services that can help citizens in their activities.

However, this requires that citizens are willing to be told by the government, receive instructions and exchange information on the e-government system. The proper functioning of these steps can ensure the success of e-government. Thus, trust becomes one of key components in enabling citizens to become willing to receive information and provide information to the e-government system in return (Lee, Braynov and Rao, 2003). Shapiro (1987) identified two types of institutions based trust; the normality of the situation, which is the belief that when situations are normal, success is likely to follow; and structural assurances which, is the belief that the presence of promises, contracts, regulations, or possible solutions to increase the chances of success guarantees. The third type of trust, knowledge based trust, is identified as familiarity with the e-vendor (Gefen, Karahanna, Straub, 2003). They argue that familiarity increases the understanding of present actions. They further state that knowledge based trust reduces the uncertainty and risk in online transactions and reduce any confusion on the use of procedures within a Web page.

\section{E-SERVICE QUALITY AS A SUCCESS MEASURE}

The quality of service is of great interest to practitioners and researchers in recent years. The quality of service is determined by the difference between the expectations of services, the provider of customer service, and evaluation of services received (Parasuraman et al., 1985, 1988). The definitions of service quality that this result was achieved for the comparison between customer expectations on service and their perceptions of how the service has been delivered and performed (Caruana 2002; Grönroos 1984; Parasuraman et al, 1985, 1988).

Li et al. (2002) developed a conceptual framework for measuring the quality of service on the Web SERVQUAL model. The study was conducted from the perspective of international clients and the survey was chosen for the data collection. The results of their study show that it is necessary to change SERVQUAL to fit better in the context of web-based service. "The quality of electronic services is the extent to which a website facilitates efficient and effective shopping, purchasing and delivery of products and services" (Zeithaml, et al. 2002).

Customers evaluate their experiences based on the service process dimension, outcome of the service, and how the company reacts when a problem occurs, and all these factors have a significant influence in determining customer satisfaction. Customers evaluate the quality of eservice, in view of the assessment of quality in the process, results and recovery experience of electronic services (Collier \& Bienstock, 2006). 


\section{PERCEIVED USEFULNESS AS A SUCCESS MEASURE}

Seddon (1997) redefined and expanded the model of DeLone and McLean IS success model, and added the perceived usefulness as an important success measure for IS success. With the information quality and system quality, perceived usefulness was included and found that the information quality and system quality are the most important factors in determining perceived usefulness. They also included perceived usefulness as a determinant of user satisfaction.

In the context of this paper, perceived usefulness is defined as "The degree to which a business user believes that using a particular e-service is useful for him or her and meets his uses goal". This view is consistent with previous studies (DeLone \& McLean, 1992; DeLone \& McLean, 2003; DeLone \& McLean, 2004; Seddon, 1997), which also found that the quality of information and benefits of a system are interrelated, and that users will perceive a web site to be of greater usefulness if it provides a higher quality of information. The higher quality of information, however, does not necessarily translate into a greater degree of ease of use for the user. Perceived usefulness of a website is increased by trust. If the users have trust in a website, they will be ready to present anything for this relationship, which will add advantage for the website. It is important when a user wants to use a website, it should be understandable and easy to use and navigate.

Accessibility is related to how the system is available, if the user wants to access the site; whether there are fewer impediments towards the user using the system as needed. This takes the user to use the system to perceive usage to be easier. Lucas and Spitler (1999) found that the system quality has an influence on the perceived usefulness and perceived ease of use. Rai et al., (2002), extended the Seddon model and identified perceived usefulness and perceived ease of use as antecedents of satisfaction.

\section{PERSONALIZATION AS A SUCCESS MEASURE}

Within the e-government context, the lack of physical contact inherent in the online experience causes customers to depend greatly on information technology (IT) behind the e-government system. IS researchers generally regarded personalization to be a highly important characteristic of all web-based ISs (Komiak and Benbasat 2006), independent of the specific application a system was designed to support such matters. In the e-commerce context, Komiak and Benbasat (2006) found that personalization influences trust in a positive way by facilitating the perceived competence of the IT artifact and the user. In turn, this study suggests that the greater the extent to which an e-government website understands and represents the personal needs of the user and the degree to which information is tailored to meet the needs of an individual user, the higher is the customer's trust. However, there has been little empirical research about the impact of personalization provided by e-government websites on trust. Therefore, this work contributes to the current knowledge about the impact of personalization on trust.

In the context of studying e-government success, a critical issue has hampered empirical investigations of the impact of customer trust on e-government success: the confusion between interpersonal trust and system trust. With interpersonal trust, trust is with a person or business, 
whereas system trust is about the reliability and security of the system (Alshibly \& Chiong, 2015).

Successful use of (ICT) creates the chance for governments to increase citizen satisfaction through government delivery of e-services. Citizen satisfaction with e-government service is related to the use of an e-government website, and citizen satisfaction is positively associated with trust in government. The increasing of the citizen trust in their government will lead to citizen satisfaction in government e-service delivery (Alshibly \& Chiong, 2015; Welch et al., 2004). Citizens perceived quality of public service delivery increases citizen satisfaction, so business users' satisfaction is strongly connected and related to trust in government service delivery (Bouckaert et al., 2002).

\section{E-GOVERNMENT}

According to Jinmei (2011) e-Government means the online supply of government information and services through the internet or other digital media. Electronic government (e-government) refers to the use of information and communication technology (ICT) tools and applications to enhance government transparency and accountability in public administration by improving public services delivery, access to information and services and public governance (Chatfield \& Alhujran, 2009; Panagiotopoulos, Al-Debei, Fitzgerald, \& Elliman, 2012).

Santos et al. (2013) refer that the function of an Electronic Government is to restructure the organization of public services, adopting mechanisms that promote communication among different entities, thus simplifying processes. The characteristics of good public governance include improved transparency and accountability. The promise of greater government transparency and accountability is often the reason for developing countries to take part in egovernment service (Chatfield \& Alanazi, 2015; Chen, Jubilado, Capistrano, \& Yen, 2015).

"Electronic Government" refers to the use by government agencies of information technologies (such as Wide Area Network (WAN), Internet and mobile computing) that has the ability to transform relations with citizens, businesses and other branches of the government (Meftah et al., 2015).

\section{INFORMATION AND COMMUNICATION TECHNOLOGY IN JORDAN}

The context for this research is the business organizations in Jordan. Jordan is a developing country in the Middle East, which has a population of about 7,500,000 and limited natural resources. It is one of the most leading countries regarding national information technology infrastructure available for Internet services. The e-Government project in Jordan is distinguished from other Arabian experiments as it is integrated at the national level over the entire kingdom which takes responsibility to form a national team working for the e-Government project so they could offer it in the rest of the government's institutions (Alawneh et al. 2013).

A revolution in ICT has changed the way of interaction between government and their citizens. These changes have turned into a new form of government called e-government. E-government is defined as: The use of ICT and internet to enhance the access to and delivery of all facets of 
government services and operations for the benefits of its stakeholder groups which includes citizens, businesses, and government itself (Srivastava \& Teo, 2008; 2009; 2010). The followed Fig.(1) is the presented research model of the conducted study.

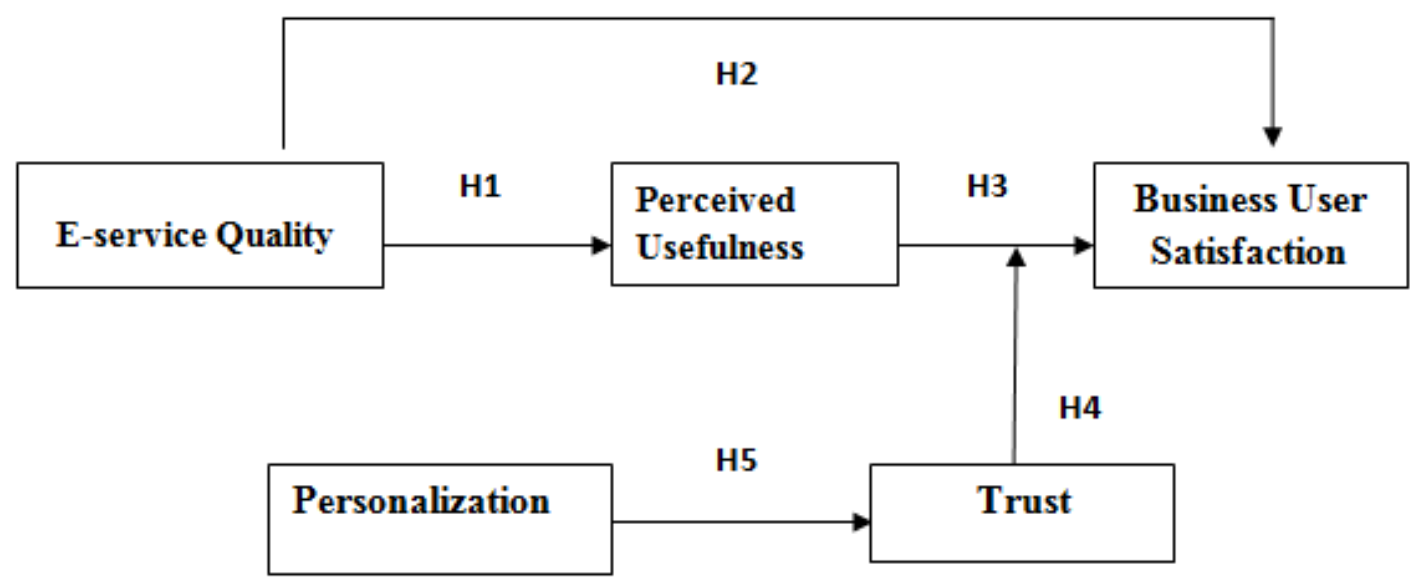

Figure 1: Presented Research Model

\section{METHODOLOGY}

\section{RESEARCH GOAL}

In this study, we aim to examine the effect of (E-service Quality, Perceived Usefulness, Personalization and Trust) on Business User Satisfaction in e-government by business users in Jordan. A structured questionnaire will be used in order to gather the data to develop the egovernment service quality scale.

\section{SAMPLE AND DATA COLLECTION}

In the current study, the sample of this study will be the business companies that use egovernment services. The data will be collected via the researchers. The questionnaire which is meant to measure the overall perceived service quality in e-government will be distributed to the targeted respondents.

Based on a comprehensive review of previous literature in the area of e-government inJordan, that have used the IS success model of Delone and Mclean plus the TAM theory using also Trust, and Personalization as success factors. The present study proposed a model of egovernment success for business organizations in Jordan. In this model, which also includes the relationships between information quality and other significant constructs, it is proposed that a study should be done to test the model empirically. In the process of developing this model, much attention is given to the measurement model of service quality in Information Systems based on the well-known Delone and Mclean IS success model, and the theory of Technology Acceptance Model. Nonetheless, the proposed model is developed based only on a theoretical perspective. The model will have to be tested empirically in order to measure its practicality and robustness. Henceforth, the model will be more conclusive and the contribution to the research area will be much more significant. 
Despite its limitation, this study provides understanding, specifically to the organizations, companies, and their respective clients, of the strengths and benefits of e-government service quality. Thus, it will help to create awareness and new knowledge regarding the importance of using e-government services through the business organizations in developing countries for the purposes among customers and vendors, hence serving as a long-term benefit to them. A better understanding and practice of e-government would increase ability in the adoption power of organizations usage and the efficiency of businesses. Moreover, this study could increase the understanding of the determinants of e-government service quality by customers and vendors, so that users' behavioral intention can benefit the e-government system. The users could also benefit from the research by knowing how to select the appropriate e-government service which can provide the e-government service quality that they seek. Other than this, the study can assist top management to develop and provide appropriate strategies to support e-government.

\section{FINDINGS}

\section{TRENDS IN E-GOVERNMENT INITIATIVES}

Governments all over the world are taking more innovative approaches in order to do business with citizens (Fang, 2002). According to Pardo (2000), e-government initiatives are citizens' access to government information; the purchase and payment, citizens have access to personal benefits, and citizen participation (voting, etc.) and others. One of the initiatives of e-government is citizens' access to government information. This type of initiative requires the establishment of a mechanism, such as a government website, such initiatives are beneficial for citizens and government by reducing distribution costs for the government, and to provide $24 \mathrm{x} 7$ access to information and materials timely updated for citizens. DeBenedictis et al. (2002) stated that to create a citizen-centered government, most e-government initiatives, internet technologies and web applications such as scholarships, online licenses, online voting and financial aid forums with elected officials. According to Lavigne (2002), four distinct perspectives can view egovernment: e-management, e-commerce, e-democracy and e-services. For this study, egovernment will be viewed from the e-services perspective.

\section{DELONE AND MCLEAN SUCCESS MODEL}

For the measurement of Information System Success, a model that was developed by DeLone and McLean (1992) that was a success measurement framework known as an IS success model. Thus, in their model, user satisfaction, system quality and information quality were identified as success criteria. The study of the IS (information system) efficiency is strongly influenced by DeLone and McLean (1992) IS success model. The model presented six key variables for success of the information system: Information Quality, User satisfaction, System Quality, Information System use, Organizational Impact Use and Individual Impact. System quality and information quality, individually and jointly affect both use and user satisfaction. In addition, the amount of use can affect positively or negatively the degree of User Satisfaction and the opposite is also true. The use and user satisfaction are direct precursors of the individual effects; Moreover, this influence should be based on individual performance may affect the organization (DeLone and Maclean, 1992). 
In the DeLone \& McLean IS Success model "System Quality" measures technical success, "Information Quality" measures semantic success and "Use, User satisfaction, Individual Impact and Organizational Impact" measures effectiveness success. DeLone and McLean updated their model and included service quality as a success measure, in the context of e-commerce based on support provided by (Pitt et al., 1995). Thus the researcher used factors from this model to carry out the study with the proper tools, the updated model for Delone and Mclean is shown in the followed Fig.(2).

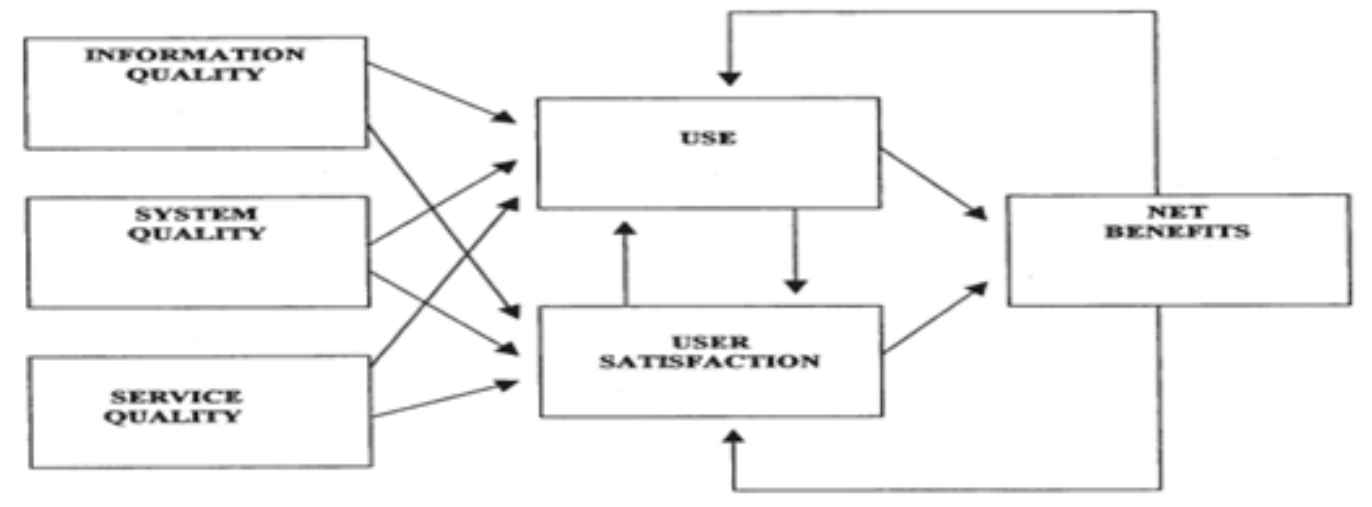

Figure 2: Updated IS success Model of DeLone\&McLean

Source: DeLone\&McLean(2003).

\section{TECHNOLOGY ACCEPTANCE MODEL (TAM)}

TAM (Davis, 1989) focuses in (on) the relationship between the causes and consequences of system design, demonstrates the usefulness, demonstrates comfort to use, attitude towards usage and the actual use behavior (Davis, Bagozzi, \& Warshaw, 1989). TAM is widely used to identify and investigate the factors of user acceptance (Yaghoubi, et al., 2010). According to Davis et al. (1989), the goal of this model is to provide insights on the determinants of acceptance of computer technology by users. Furthermore, this model is able to explain user behavior across various populations and standard space for using computer technology through theoretical justification (Davis et al., 1989). Use of TAM has been widely supported in empirical studies (Ajzen, 1991; Davis et al., 1989; Suki \& Ramayah, 2010; Yaghoubi, et al., 2010). In summary, this model provides information on a mechanism in which the selection of the design can affect the user acceptance and it also serves to be applied in the context of forecasting and evaluation of a user acceptance of IT. The researcher is going to choose the suitable factors to carry out this investigation, the TAM model shall be produced in the following Fig.(3).

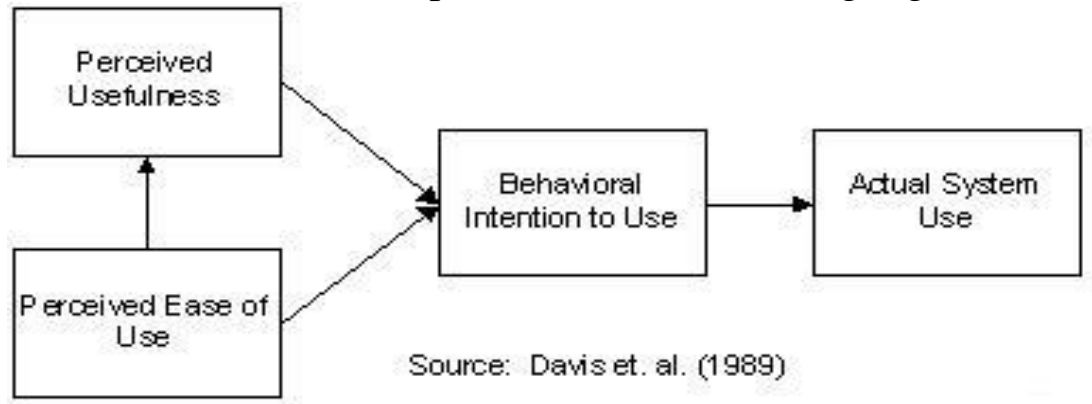

Figure 3: Theory of Technology Acceptance Model

Source: Davis et al. (1989) 


\section{CONCLUSION}

The main purpose of the study is proposing a success factors model in e-government service that leads the Jordanian business organizations to adopt the e-government services. The results would help authorities and business organizations to understand the key issues that influence business need and satisfaction with the presented services and they can use these criteria to judge their services delivery process to achieve the goal of making the business organizations' adopt the egovernment technology. Nowadays the smooth moving of information all over the world becomes the basic aspect of our new e-life. Furthermore electronic governments extends public services beyond the walls of the government institutions to anytime anywhere applied service therefore the outcome of this research will provide understanding of the strengths and benefits, specifically to the Jordanian government and business organizations for quality of e-government services in Jordanian electronic government that affects the adoption of e-government services. This study is initiated recognizing a need for research into an area. As e-government portals provide the Jordanian business organizations the ability to access its services despite the location and time, plus it satisfies their needs by allowing them to achieve their goals. In addition egovernment allows flexibility in delivering institution services. The government e-service website has offered citizens what technology has made possible to deliver, rather than first asking what is it the citizens want delivered to them. Therefore, the researcher has stressed the need to focus on what makes the citizen as a customer satisfied in obtaining the service, and the need to measure such satisfaction. In view of this, service quality of electronic government could bridge the gap in communication between citizens and governments. As e-government portals provide the Jordanian citizens the ability to access its services despite the location and time, plus it satisfies their needs by allowing them to achieve their goals. In addition e-government allows flexibility in delivering institution services.

\section{REFERENCES}

[1] Ancarani, A. (2005). Towards quality e-service in the public sector:: The evolution of web sites in the local public service sector. Managing Service Quality, 15(1), 6-23.

[2] Al Hujran, O., Aloudat, A., \& Altarawneh, I. (2013). Factors influencing citizen adoption of e-government in developing countries: The case of Jordan. International Journal of Technology and Human Interaction (IJTHI), 9(2), 1-19.

[3] Alshibly, H., \& Chiong, R. (2015). Customer empowerment: Does it influence electronic government success? A citizen-centric perspective. Electronic Commerce Research and Applications, 14(6), 393-404.

[4] Al-Jaghoub, S., Al-Yaseen, H., \& Al-Hourani, M. (2010). Evaluation of awareness and acceptability of using e-government services in developing countries: The case of Jordan. The Electronic Journal Information Systems Evaluation, 13(1), 1-8.

[5] Abdalla, S. (2012). An e-government adoption framework for developing countries: a case study from Sudan (Doctoral dissertation, Cranfield University).

[6] Alomari, M. K., Sandhu, K., \& Woods, P. (2009, November). E-government adoption in the Hashemite Kingdom of Jordan: factors from social perspectives. In Internet Technology and Secured Transactions, 2009. ICITST 2009. International Conference for (pp. 1-7). IEEE. 
[7] Alomari, M., Sandhu, K., \& Woods, P. (2010). Measuring social factors in e-government adoption in the Hashemite Kingdom of Jordan. International Journal of Digital Society (IJDS), 1(2), 163-172.

[8] Alawneh, A., Al-Refai, H., \& Batiha, K. (2013). Measuring user satisfaction from eGovernment services: Lessons from Jordan. Government Information Quarterly, 30(3), 277-288.

[9] Alomari, M. K. (2014). Discovering citizens reaction toward e-government: factors in egovernment adoption. JISTEM-Journal of Information Systems and Technology Management, 11(1), 5-20.

[10] Alomari, M. K., Sandhu, K., \& Woods, P. (2014). Exploring citizen perceptions of barriers to e-government adoption in a developing country. Transforming Government: People, Process and Policy, 8(1), 131-150.

[11] Ajzen, I. (1991). The theory of planned behavior. Organizational behavior and human decision processes, 50(2), 179-211.

[12] Bouckaert, G., Van de Walle, S., Maddens, B., \& Kampen, J. K. (2002). Identity vs Performance: An overview of theories explaining trust in government. Second Report. Leuven: Public Management Institute.

[13] Ciborra, C., \& Navarra, D. D. (2005). Good governance, development theory, and aid policy: Risks and challenges of e-government in Jordan. Information technology for development, 11(2), 141-159.

[14] Caruana, A. (2002). Service loyalty: The effects of service quality and the mediating role of customer satisfaction. European journal of marketing, 36(7/8), 811-828.

[15] Collier, J. E., \& Bienstock, C. C. (2006). Measuring service quality in e-retailing. Journal of service research, 8(3), 260-275.

[16] Carter, L., \& Bélanger, F. (2005). The utilization of e-government services: citizen trust, innovation and acceptance factors*. Information Systems Journal,15(1), 5-25.

[17] Chang, I-Chiu; Li, Yi-Chang; Hung, Won-Fu \& Hwang, Hisn-Ginn, 2005. An empirical study on the impact of quality antecedents on tax payers acceptance of internet tax-filing systems. Government Information Quarterly, vol.22, pp. 389-410.

[18] Chatfield, A. T., \& Alhujran, O. (2009). A cross-country comparative analysis of $e$ government service delivery among Arab countries. Information Technology for Development, 15(3), 151-170.

[19] Chatfield, A. T., \& AlAnazi, J. (2015). Collaborative Governance Matters to EGovernment Interoperability: An Analysis of Citizen-Centric Integrated Interoperable EGovernment Implementation in Saudi Arabia. International Journal of Public Administration in the Digital Age (IJPADA), 2(3), 24-44.

[20] Chen, J. V., Jubilado, R. J. M., Capistrano, E. P. S., \& Yen, D. C. (2015). Factors affecting online tax filing-An application of the IS Success Model and trust theory. Computers in Human Behavior, 43, 251-262.

[21] Davis, F. D. (1989). Perceived usefulness, perceived ease of use, and user acceptance of information technology. MIS quarterly, 319-340.

[22] Davis, F.D., Bagozzi, R.P., and Warshaw, P.R.,1989. User Acceptance of Computer Technology: A Comparison of Two Theoretical Models, Management Science (35) 1989, pp 982-1003. 
[23] Delone, W. H., \& McLean, E. R. (2003). The DeLone and McLean model of information systems success: a ten-year update. Journal of management information systems, 19(4), 9-30.

[24] Delone, W. H., \& Mclean, E. R. (2004). Measuring e-commerce success: Applying the DeLone \& McLean information systems success model. International Journal of Electronic Commerce, 9(1), 31-47.

[25] DeLone, W. H., \& McLean, E. R. (1992). Information systems success: The quest for the dependent variable. Information systems research, 3(1), 60-95.

[26] DeBenedictis, A., Howell, W., Figueroa, R., \& Boggs, R. (2002). E-government defined: an overview of the next big information technology challenge. Issues in Information Systems, 3(1), 130-136.

[27] Fang, Z. (2002). E-government in digital era: concept, practice, and development. International journal of the Computer, the Internet and management, 10(2), 1-22.

[28] Gilbert, D., Balestrini, P., \& Littleboy, D. (2004). Barriers and benefits in the adoption of e-government. International Journal of Public Sector Management, 17(4), 286-301.

[29] Grönroos, C. (1984). A service quality model and its marketing implications. European Journal of marketing, 18(4), 36-44.

[30] Gefen, D., Karahanna, E., \& Straub, D. W. (2003). Trust and TAM in online shopping: an integrated model. MIS quarterly, 27(1), 51-90.

[31] Jinmei, H. (2011, August). Quality evaluation of e-government public service. In Management and Service Science (MASS), 2011 International Conference on (pp. 1-4). IEEE.

[32] Komiak, S. Y., \& Benbasat, I. (2006). The effects of personalization and familiarity on trust and adoption of recommendation agents. MIS quarterly, 941-960.

[33] Li, Y. N., Tan, K. C., \& Xie, M. (2002). Measuring web-based service quality. Total quality management, 13(5), 685-700.

[34] Lucas, H. C., \& Spitler, V. K. (1999). Technology use and performance: A field study of broker workstations. Decision sciences, 30(2), 291-311.

[35] LaVigne, M. F., Pagano, C. M., Dawes, S. S., \& Pardo, T. A. (2002). Making a case for local e-government. Center for Technology in Government, University at Albany, SUNY.

[36] Lee, J. K., Braynov, S., \& Rao, R. (2003). Effects of public emergency on citizens' usage intention toward e-Government: a study in the context of war in Iraq. ICIS 2003 proceedings, 83.

[37] Meftah, M., Gharleghi, B., \& Samadi, B. (2015). Adoption of E-Government among Bahraini Citizens. Asian Social Science, 11(4), p141.

[38] Mofleh, S. I., \& Wanous, M. (2008). Understanding factors influencing citizens' adoption of e-government services in the developing world: Jordan as a case study. INFOCOMP Journal of Computer Science, 7(2), 1-11.

[39] Morgeson, F. V., VanAmburg, D., \& Mithas, S. (2010). Misplaced trust? Exploring the structure of the e-government-citizen trust relationship. Journal of Public Administration Research and Theory, muq006.

[40] Phang, C. W., Li, Y., Sutanto, J., \& Kankanhalli, A. (2005, January). Senior citizens' adoption of e-government: in quest of the antecedents of perceived usefulness. In System Sciences, 2005. HICSS'05. Proceedings of the 38th Annual Hawaii International Conference on (pp. 130a-130a). IEEE. 
[41] Parasuraman, A., Zeithaml, V. A., \& Berry, L. L. (1985). A conceptual model of service quality and its implications for future research. the Journal of Marketing, 41-50.

[42] Parasuraman, A., Zeithaml, V. A., \& Berry, L. L. (1988). Servqual. Journal of retailing, 64(1), 12-40.

[43] Panagiotopoulos, P., Al-Debei, M. M., Fitzgerald, G., \& Elliman, T. (2012). A business model perspective for ICTs in public engagement. Government Information Quarterly, 29(2), 192-202.

[44] Pitt, L. F., Watson, R. T., \& Kavan, C. B. (1995). Service quality: a measure of information systems effectiveness. MIS quarterly, 173-187.

[45] Pardo, T. (2000). Realizing the promise of digital government: It's more than building a web site. Albany, NY: Center for Technology in Government.

[46] Rana, N. P., Dwivedi, Y. K., Williams, M. D., \& Weerakkody, V. (2015). Investigating success of an e-government initiative: Validation of an integrated IS success model. Information Systems Frontiers, 17(1), 127-142.

[47] Rai, A., Lang, S. S., \& Welker, R. B. (2002). Assessing the validity of IS success models: An empirical test and theoretical analysis. Information systems research, 13(1), 50-69.

[48] Santos, P., Melo, A. I., \& Paiva Dias, G. (2013, June). Administrative modernisation and e-government: The case of Águeda. In Information Systems and Technologies (CISTI), 2013 8th Iberian Conference on (pp. 1-6). IEEE.

[49] Srivastava, S. C., Teo, T. S., \& Jiang, L. (2008). Trust and electronic government success: An empirical study. Journal of Management Information Systems, 25(3), 99-132.

[50] Srivastava, S. C., \& Teo, T. S. (2009). Citizen trust development for e-government adoption and usage: Insights from young adults in Singapore. Communications of the Association for Information Systems, 25(1), 31.

[51] Srivastava, S. C., \& Teo, T. S. (2010). E-government, e-business, and national economic performance. Communications of the Association for Information Systems, 26(1), 14.

[52] Suki, N. M., \& Ramayah, T. (2010). User acceptance of the e-government services in Malaysia: structural equation modelling approach. Interdisciplinary Journal of Information, Knowledge, and Management, 5(1), 395-413.

[53] Shapiro, S. P. (1987). The social control of impersonal trust. American journal of Sociology, 623-658.

[54] Seddon, P. B. (1997). A respecification and extension of the DeLone and McLean model of IS success. Information systems research, 8(3), 240-253.

[55] Welch, E. W., Hinnant, C. C., \& Moon, M. J. (2005). Linking citizen satisfaction with egovernment and trust in government. Journal of public administration research and theory, 15(3), 371-391.

[56] Yaghoubi, N. M., Kord, B., \& Shakeri, R. (2010). E-government services and user acceptance: the unified models' perspective. European Journal of Economics, Finance and Administrative Sciences, 24, 36-49.

[57] Zeithaml, V. A., Parasuraman, A., \& Malhotra, A. (2002). Service quality delivery through web sites: a critical review of extant knowledge. Journal of the academy of marketing science, 30(4), 362-375. 